九州大学学術情報リポジトリ

Kyushu University Institutional Repository

\title{
Injury of Escherichia coli K12 by Hydrostatic Pressure Treatment with Rapid Decompression
}

Noma, Se i j i

Laboratory of Food Process Engineering, Division of Food Process Engineering, Division of Food Biotechnology, Department of Bioscience and Biotechnology, Graduate School of Bioresource and Bioenvi ronmental Sciences, Kyushu University

Shimoda, Mitsuya

Laboratory of Food Process Engineering, Division of Food Biotechnology, Department of Bioscience and Biotechnology, Faculty of Agriculture, Kyushu University

Hayakawa, Isao

Laboratory of Food Process Engineering, Division of Food Biotechnology, Department of Bioscience and Biotechnology, Faculty of Agriculture, Kyushu University

https://doi.org/10.5109/4538

出版情報 : 九州大学大学院農学研究院紀要. 48 (1/2), pp. 153-158, 2003-10-01. Faculty of Agriculture, Kyushu University

バージョン :

権利関係 : 


\title{
Injury of Escherichia coli K12 by Hydrostatic Pressure Treatment with Rapid Decompression
}

\author{
Seiji NOMA*+, Mitsuya SHIMODA and Isao HAYAKAWA \\ Laboratory of Food Process Engineering, Division of Food Biotechnology, \\ Department of Bioscience and Biotechnology, Faculty of Agriculture, \\ Kyushu University, Fukuoka 812-8581, Japan \\ (Received June 30, 2003 and accepted July 15, 2003)
}

\begin{abstract}
We previously found that hydrostatic pressure treatment combined with a rapid decompression (about $2 \mathrm{~ms}$; RD treatment) had a higher bactericidal effect than that with a slow decompression (about $30 \mathrm{~s}$; SD treatment). To further improve the bactericidal efficiency, it is important to make clear the mechanistic aspects of the RD treatment. Therefore, in the present study we tried to detect the injury of Escherichia coli K12 cells using the differential plating method with selective and non-selective agar plates after the SD and RD treatments at $300 \mathrm{MPa}$ and $25^{\circ} \mathrm{C}$. The results obtained suggested that the RD treatment had no additional effect on reducing the cellular ability to synthesize essential components. However, the RD treatment accelerated the damages to cell envelope including outer membrane and cytoplasmic membrane compared to the SD treatment. Therefore, it was expected that the envelope damages were one of the major targets of the RD treatment.
\end{abstract}

\section{INTRODUCTION}

Food stabilization requires efficient microbial and enzyme destruction or inhibition. Heat treatment, commonly used to destroy microorganisms and inactivate enzymes, may have negative effects on some food properties such as color, flavor and nutrient. The hydrostatic pressure treatment (HPT) has been the subject of increasing investigation as an alternative food processing method. The advantages of HPT are to allow improved retention of quality parameters such as flavors, taste and nutrients and that may enable to produce high quality food products (Cheftel, 1992). However, the use of high-pressure treatment may not be commercially available because very high pressures are required for the inactivation of microorganisms and enzymes. This leads to increase of the equipment costs in addition to the problem of metal fatigue (Hoover, 1993). Decrease of the processing pressure is the most important point for the resolution of this problem (Furukawa, et al. 2000).

Hayakawa et al. (1998) contrived "Rapid decompression (RD) method" to increase the bactericidal effect of hydrostatic pressure treatment. This RD treatment is achieved by a rapid decompression procedure after a pressure holding process. The pressure holding process ensures the penetration of water into the microbial cells, and the subsequent explosive decompression results in a fast adiabatic expansion of water within the cells. As

\footnotetext{
* Laboratory of Food Process Engineering, Division of Food Biotechnology, Department of Bioscience and Biotechnology, Graduate School of Bioresource and Bioenvironmental Sciences, Kyushu University, Fukuoka 812-8581, Japan

+ Corresponding author (E-mail: nomas@agr.kyushu-u.ac.jp)
} 
the result, an impulsive force acts on the inner surface of the cells and that results in a cellular physical destruction. The inactivation effect caused by a combination of this impulsive force and the pressurization is expected to be much larger than that caused by the pressurization alone. We already confirmed the RD method had an additional efficiency in spore and cell destruction using the spores of Bacillus stearothermophilus (Hayakawa, et al., 1998), the cells of Escherichia coli, Salmonella typhimurium, Pseudomonus aeruginosa and Vibrio parahaemoluticus (Noma et al., 2002) as test strains. However, we have no information on the mechanistic aspects of cell death by the $\mathrm{RD}$ treatment. Practical application of the sterilization method requires insight into the mechanisms because their elucidation will help to select the optimal condition of the RD treatment.

The differential plating method has been successfully used for detecting and specifying the injury of microbial cells. In this study we tried to explore the possible lethal targets of the RD treatment using the differential plating method with selective and non-selective agar plates.

\section{MATERIALS AND METHODS}

\section{Bacterium and preparation of cell suspension}

Escherichia coli $\mathrm{K} 12$ was kindly provided by the National Institute of Genetics (Shizuoka, Japan). The cells were propagated at $30^{\circ} \mathrm{C}$ for $12 \mathrm{~h}$ in $10 \mathrm{ml}$ of tryptic soy broth (Difco, Detroit, Michigan, USA) and washed and harvested three times by centrifugation at $2,000 \times g$ and $4^{\circ} \mathrm{C}$ for $10 \mathrm{~min}$ in $0.9 \%(\mathrm{w} / \mathrm{v}$ ) sodium chloride (Nacalai Tesque, Inc., Kyoto, Japan) solution. The resulting cell pellet was re-suspended in the same solution to give approximately $10^{7} \mathrm{CFU} / \mathrm{ml}$ of final density. The cell suspensions were stored at $4^{\circ} \mathrm{C}$ until use.

\section{Hydrostatic pressure treatment with a slow or a rapid decompression procedure}

The prepared cell suspensions were sealed in $1.5 \mathrm{ml}$ sterile screw capped plastic sample tubes (Greiner Labortechnik, Kremsmüenster, Germany) and subjected to the following two treatments. The first is a SD treatment, which was defined as HPT combined with a slow decompression procedure. This SD treatment was carried out as a model of conventional HPT. The decompression time from the desired pressure to atmospheric pressure was about $30 \mathrm{~s}$. A non-rotational rod valve (Hayakawa, et al., 1998) was used for this decompression procedure. The other is a RD treatment, which was defined as HPT combined with a rapid decompression procedure. A link-motion system was used for the rapid decompression treatment. The details of the operation and decompression mechanism were described in a previous paper (Hayakawa, et al., 1998). The time needed to complete the rapid decompression from the desired pressure to atmospheric pressure was about $2 \mathrm{~ms}$. The SD and RD treatments were carried out at $300 \mathrm{MPa}$ and $25^{\circ} \mathrm{C}$. The treatment period was defined as the pressure holding period at $300 \mathrm{MPa}$. The $0 \mathrm{~min}$ treatment was carried out by the decompression just after pressure come-up to the desired pressure. The temperature during both treatments was controlled by a thermocontroller NCB-2400 (Tokyo Rikakikai, Tokyo, Japan). 


\section{Differential plating method}

Cell injury was detected with the differential-plating method. The non-selective agar plate used was tryptic soy agar (TSA; Difco). The selective agar plates used were TSA supplemented with chloramphenicol (Nacalai Tesque), TSA supplemented with $\mathrm{NaCl}$ and minimum agar, which contained $\mathrm{K}_{2} \mathrm{HPO}_{4} 7.0 \mathrm{~g}, \mathrm{KH}_{2} \mathrm{PO}_{4} 3.0 \mathrm{~g}$, sodium citrate $\cdot 2 \mathrm{H}_{2} \mathrm{O} 0.1 \mathrm{~g}$, $\mathrm{MgSO}_{4} \cdot 7 \mathrm{H}_{2} \mathrm{O} 0.1 \mathrm{~g},\left(\mathrm{NH}_{4}\right)_{2} \mathrm{SO}_{4} 1.0 \mathrm{~g}$, glucose $2.0 \mathrm{~g}$, and agar $15 \mathrm{~g}$ in $1 \mathrm{~L}$ of distilled water. All chemicals used for the minimum agar were obtained from Nacalai Tesque. To determine the maximum concentration of chloramphenicol and $\mathrm{NaCl}$ without inhibition of colonization of intact $E$. coli $\mathrm{K} 12$ cells $\left(C_{\max }\right)$, effect of concentration of each reagent on the colony count of intact $E$. coli $\mathrm{K} 12$ cells was investigated (Fig. 1). The determined $C_{\max }$ of chloramphenicol and $\mathrm{NaCl}$ was $2.0 \mu \mathrm{g} / \mathrm{ml}$ and $25 \mathrm{mg} / \mathrm{ml}$, respectively. After the SD and RD treatments, appropriate serial dilutions were prepared using $0.9 \%$ sodium chloride solution as a diluent, and $0.1 \mathrm{ml}$ volume of the suspension was plated onto both the TSA and the selective agar plates. The number of colonies formed on each plate medium was counted after incubation at $30^{\circ} \mathrm{C}$ for $72 \mathrm{~h}$. The number of sensitized cells to the selective agar $\left(N_{s}\right)$ was defined as $N_{s}=N_{t}-N_{u s}$, where $N_{t}$ and $N_{u s}$ were the number of colonies formed on the non-selective and the selective agar plates, respectively.
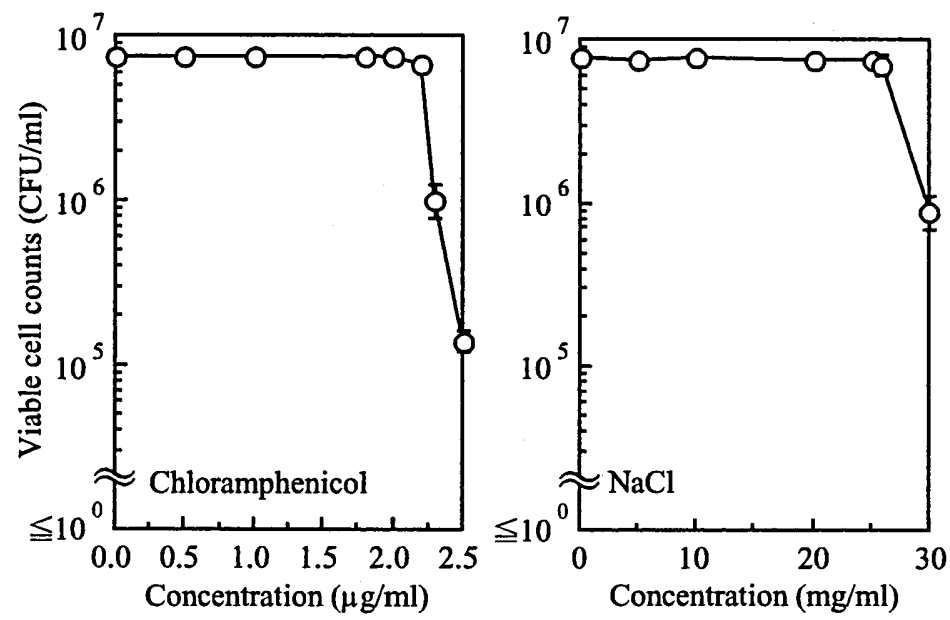

Fig. 1. Effect of concentration of each selective reagent on colony counts of intact $E$. coli $\mathrm{K} 12$ cells. Symbols represent mean of three independent experiments \pm standard error.

\section{Statistical analysis}

All experiments were performed in triplicate. The data presented are the means of triplicate experiments. Significant difference was determined with $5 \%$ level of significance $(P<0.05)$ by Student's $t$ test. 


\section{RESULTS AND DISCUSSION}

\section{Damage of outer membrane}

The main structure of outer membrane of $E$. coli cells is lipopolysaccharide (LPS) bilayer. Since the LPS is hydrophilic substance, outer membrane acts as a barrier for hydrophobic substances including chloramphenicol, which is an antibiotic and act as an inhibitor for protein synthesis (Pongs et al., 1973; Vester and Garrett, 1988). In addition, cell envelopes including outer membrane possess drug-efflux system, which pumping out various unacceptable agents such as antibiotics and bile salt (Nikaido, 1996). Therefore, the sensitization of $E$. coli cells to chlorampheniol can be regarded as damage of outer membrane.

The effects of the SD and RD treatments on the number of colonies formed on the TSA and the TSA supplemented with chloramphenicol are shown in Fig. 2 (A). In the SD treatment, the $0 \mathrm{~min}$ treatment, namely the decompression was done just after the pressure come-up, caused no reduction in the colony number of $E$. coli K12 cells on both the TSA and the TSA with chloramphenicol. The sensitivity of $E$. coli K12 cells to chloramphenicol was significantly $(P<0.05)$ increased after the SD treatments for longer than $10 \mathrm{~min}$.

In the RD treatment, the 0 min treatment did not affect the colony number on both the TSA and the TSA with chloramphenicol. The RD treatments longer than 5 min sensitized $E$. coli K12 cells to chloramphenicol. The degrees of sensitization to chloramphenicol caused by the RD treatments were larger than those by the SD treatments.

From these results it is suggested that the RD treatment has an additional effect on enhancing the outer membrane damage of $E$. coli K12 cells. It is considered that this outer membrane damage of $E$. coli $\mathrm{K} 12$ cells is related to the increased inactivation effect in the RD treatment.

\section{Envelope damage}

The exposure of $E$. coli cells to an excessive high osmotic pressure results in the damage of the cell envelopes, because the dehydration with the exposure yields a cellular shrinkage. Since $E$. coli cells that suffered injury to the cell envelopes including cytoplasmic membrane become sensitive to $\mathrm{NaCl}$ (Gilbert, 1984), cell envelope damages by the SD and the RD treatments were enumerated as a difference of the formed colony number between the TSA and the TSA supplemented with $25 \mathrm{mg} / \mathrm{ml} \mathrm{NaCl}$. The results are shown in Fig. 2 (B).

In the SD treatment, the 0 min treatment did not decrease the cell counts on both the TSA and the TSA with NaCl. The viable counts on both the TSA and the TSA with $\mathrm{NaCl}$ decreased with the pressure holding time elapsed. The reduction rate of the colony number on the TSA with $\mathrm{NaCl}$ was larger than that on the TSA. In the RD treatment, the 0 min treatment did not decrease the number of colonies formed on the TSA, however this treatment significantly $(P<0.05)$ decreased the counts on the TSA with $\mathrm{NaCl}$. The decrease in the viable colonies on the TSA and the TSA with $\mathrm{NaCl}$ became more pronounced as the pressure holding time elapsed, and these behaviors were more striking than the SD treatment.

From these results, it is suggested that the RD treatment has an additional effect on 
causing the envelope damages to $E$. coli $\mathrm{K} 12$ cells. It is considered that the enhanced envelope damage is related to the increased inactivation effect in the RD treatment. In addition, the $\mathrm{RD}$ treatment for 0 min sensitized to $\mathrm{NaCl}$, indicating that the rapid decompression process itself could cause damage to $E$. coli $\mathrm{K} 12$ cell envelopes.

\section{Damage of the synthesis ability of essential components}

Decrease in the ability of $E$. coli cells to synthesize essential cellular components is evidenced by a lowering of the cellular ability to multiply on nutritionally poor media (Straka and Stokes, 1959), because the cells with the lowered ability hardly use the nutrients contained in the nutritionally poor media. Therefore, the effects of the SD and $\mathrm{RD}$ treatments on the ability of $E$. coli $\mathrm{K} 12$ cells to synthesize essential cellular components can be monitored by comparing the number of colonies formed on the TSA (rich in nutrients) and the minimum agar plate (nutritionally poor medium). The results are shown in Fig. 2 (C).

The SD treatment for 0 min had no effect on decreasing the colony counts on both the TSA and the minimum agar media. The SD treatment for 2 min decreased the number of colonies formed on both media. However, the colony numbers on the minimum agar were similar to that on the TSA. After the SD treatments longer than $3 \mathrm{~min}$, the colony counts on the minimum agar were significantly $(P<0.05)$ lower than those on the TSA. The differences in the colony counts between the TSA and the minimum agar increased with the treatment time elongated.

The RD treatment for 0 min caused no decrease of the colony counts on both the TSA and the minimum agar. The RD treatment for $2 \mathrm{~min}$ decreased the number of colonies formed on both the TSA and the minimum agar at the same level. After the RD treatments longer than $3 \mathrm{~min}$, the colony numbers on the minimum agar were significantly
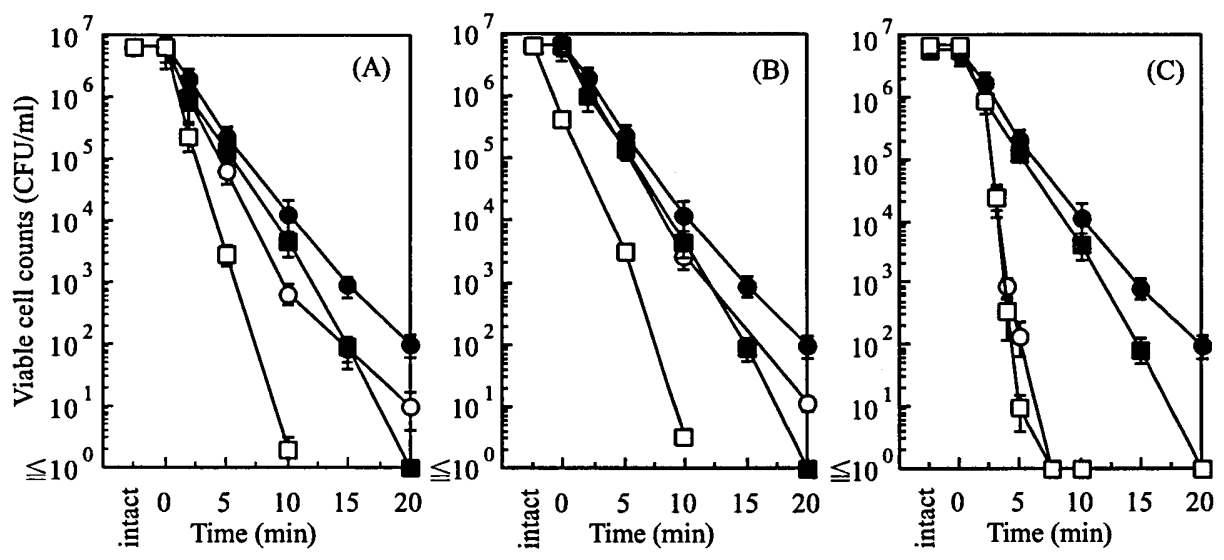

Fig. 2. Effects of the SD (circle) and RD (square) treatments on the viable counts of $E$. coli $\mathrm{K} 12$ cells on non-selective (black) and selective (white) agar plates. Both the SD and RD treatments were carried out at $300 \mathrm{MPa}$ and $25^{\circ} \mathrm{C}$. Selective agars used were TSA with $2.0 \mu \mathrm{g} / \mathrm{ml}$ of chloramphenicol (A), TSA with $25 \mathrm{mg} / \mathrm{ml}$ of $\mathrm{NaCl}$ (B) and minimum agar (C). Symbols represent mean of three independent experiments \pm standard error. 
$(P<0.05)$ lower than those on the TSA. The differences in the colony counts between the TSA and the minimum agar after the RD treatments were similar to those after the SD treatments.

From these results, it is suggested that both the SD and RD treatments decrease the ability of $E$. coli $\mathrm{K} 12$ cells to synthesize essential cellular components. However, the RD treatment has no additional effect on decreasing this ability, suggesting that the decrease in the ability to synthesize the essential cellular components does not relate to the higher inactivation effect of the RD treatment.

In the present study we tried to detect the injury of $E$. coli $\mathrm{K} 12$ cells using the differential plating method with selective and non-selective agar plates after the SD and $\mathrm{RD}$ treatments at $300 \mathrm{MPa}$ and $25^{\circ} \mathrm{C}$. The results obtained suggest that the RD treatment accelerate the damages to cell envelope including outer membrane and cytoplasmic membrane compared to the SD treatment. Therefore, it is expected that the envelope damages are one of the major targets of the RD treatment and the combination use of any treatment, which increasing their damage improves the inactivation effect of the RD treatment.

\section{ACKNOWLEDGEMENT}

We thank the National Institute of Genetics for kindly providing a strain of $E$. coli K12 used in this study.

\section{REFERENCES}

Cheftel, J. C. 1992 Effects of high hydrostatic pressure on food constituents: an overview. In "High Pressure Biotechnology", ed. by Balny, C., R. Hayashi, K. Heremans and P. Masson. Colloque INSERM/John Libbey, London, pp. 185-193

Furukawa, S., A. Nakahara, and I. Hayakawa 2000 Effect of reciprocal pressurization on germination and killing of bacterial spores. Int. J. Food Sci. and Technol., 35: 529-532

Gilbert, P. 1984 The revival of microorganisms sub-lethally injured by chemical inhibitors. In "The Revival of Injured Microbes", ed. by Andrew, M. H. E. and Russell, A. D., Academic Press, Inc., London, pp. 175-197

Hayakawa, I., S. Furukawa, A. Midzunaga, H. Horiuchi, T. Nakashima, Y. Fujio, Y. Yano, T. Ishikura and K. Sasaki 1998 Mechanism of inactivation of heat-tolerant spores of Bacillus stearothermophilus IFO 12550 by rapid decompression. J. Food Sci., 63: 371-374

Hoover, D. G. 1993 Pressure effects on biological systems. Food Technol., 47: 150-155

Nikaido, H. 1996 Multidrug efflux pumps of gram-negative bacteria. J. Bacteriol., 178: 5853-5859

Noma, S., Shimoda, M. and Hayakawa, I. 2002 Inactivation of vegetative bacteria by rapid decompression treatment. J. Food Sci., 67: 3408-3411

Pongs, O., Bald, R. and Erdmann, V. A. 1973 Identification of chloramphenicol-binding protein in Escherichia coli ribosomes by affinity labeling. Proc. Natl. Acad. Sci. U. S. A., 70: 2229-2233

Straka, R. P. and Stokes, J. L. 1959 Metabolic injury to bacteria at low temperatures. J. Bacteriol., 78: 181-185

Vester, B. and Garrett, R. A. 1988 The importance of highly conserved nucleotides in the binding region of chloramphenicol at the peptidyl transfer cetre of Escherichia coli $23 \mathrm{~S}$ ribosomal RNA. EMBO J., 7: 3577-3587 